\section{SELECTED DOCUMENTS}

Draft Principles of Conduct in the Field of the Environment for the Guidance of States in the Conservation and Harmonious Utilization of Natural Resources Shared by Two or More States

Allocution Prononcée par Valéry Giscard d'Estaing

Convention sur le Commerce International des Espèces de Faune et de Flore Sauvages menacées d'Extinction

Draft Resolution on a Law of the Sea

Recommendation of the OECD Council for the Implementation of a Regime of Equal Right of Access and Non-Discrimination in Relation to Transfrontier Pollution

Draft EEC Council of Ministers Recommendation to the Member States Regarding Methods of Evaluating the Cost of Pollution Con trol to Industry

Written Question by Edgar Jahn to the Commission of the European Communities regarding Attribution of Powers in the Field of the Environment to the European Communities by Amending the EEC Treaty

Conservation and the New Law of the Sea

The European Citizen and his Environment

Kuwait Action Plan for the Marine Environment (Extracts)

Kuwait Regional Convention for Cooperation on the Protection of the Marine Environment from Pollution

Follow-up to Conference on Desertification

Draft Convention on Deterioration of the Marine Environment as a Result of Exploration and Exploitation of the Seabed and its Subsoil in Maritime Areas under the National Jurisdiction of States

Arrêté du 11 Mai 1978 Portant Agrément de la Société Française pour le Droit de 1'Environnement
UNEP 6 th Governing Council:

- Programme Policy and Implementation

- Environment and Development

- International Referral System

- Environmental Law 142

- Secretariat of CITS 143

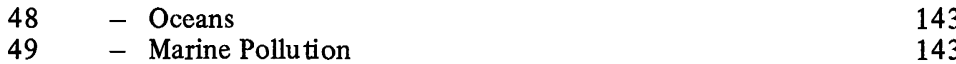

ESCAP/UNEP Expert Group Meeting on Environmental Pro-

$\begin{array}{lll}51 & \text { tection Legislation (Conclusions and Recommendations) } & 184 \\ 52 & \text { France - Senat-Amoco Cadiz } & 185\end{array}$

Recommendation 847 (1978) (1) on European Action to Prevent Oil Pollution of Waters and Coasts 186

53 Environmental Report of Germany, FR 186

IUCN Resolutions (14th General Assembly)

- World Heritage Natural Sites

- Environmental Effects of Sulphur Dioxide Pollution $\quad 190$

- Conservation for Development 190

- Convention on International Trade in Endangered Species of Wild Fauna and Flora

- Wadden Sea

- Marine Oil Tankers - Pollution 190

Draft Convention for the ECE Region on Reduction of Emissions Causing Transboundary Air Pollution 191

$\begin{array}{lll}133 & \text { CEDE - Guiding Principles for Impact Assessment Procedure } & 193 \\ 136 & \text { UK - House of Lords - EEC Article 100 Report } & 193\end{array}$

OECD -

- Recommendation for Strengthening International Cooperation on Environmental Protection in Frontier Regions 195

- Recommandation pour le Renforcement de la Coopération Internationale en vue de la Protection de l'Environnement des Régions Frontières

\title{
Author Index of Volume 4
}

Alheritière, D., 19

Bridgeman, James C., 69

Brown Weiss, Edith, 22

Carpentier, M., 1

de Klemm, Cyrille, 2

Dhoore, M. L., 43

Echeverria Alvarez, H. E. Luis, 159

Forster, Malcolm, 28

Gospodarek, Mary P., 58, 170

Graham, Garry, 69

Heimann, Karla, 30
Henry, Christian, 176

Hucke, John, 109

Irwin, William A., 30

Jackson, C. I., 85

Johnston, Douglas M., 78

Kimball, Lee, 69, 146

McCloskey, Maxine, 26

Malanczuk, Peter, 29

Martray, Joseph, 172

Mitchell, Heather, 91

Müller, Edda, 34

Nagel, Stefan, 167
Rehbinder, Eckhard, 167

Schneider, Adolf R. H., 69, 146

Seidl-Hohenveldern, Ignaz, 20

Shane, Jeffrey N., 152

Siebker, M. H., 87

Stutzin, Godofredo, 56

Tolba, Mostafa K., 40

Van Beek, Drake, 58, 181

von Moltke, Konrad, 101

Willheim, Ernst, 104

Yeany, Philip R., 115

Zalob, David S., 121

ERRATUM: The name of Stefan Nagel was inadvertently omitted from the list of Associate Editors in the Impressum of issue number $2 / 3$ of this volume. 